\title{
Theory and Practice of Wildland Fuels Management
}

\author{
Philip N. Omi ${ }^{1}$
}

Published online: 28 April 2015

(C) Springer International Publishing AG 2015

\begin{abstract}
Fuel treatments have become an indispensable tool for managing fire in North American wildland ecosystems. Historical perspective and extant practices provide insights into current theory and areas of future emphasis. Managers have better understanding of treatment practices as researchers have provided clearer understanding of fire behavior in treated vs. untreated areas and enhanced wisdom about ecological effects in a variety of fire regimes. Even so, recent breakthroughs in the theory and practice of fuels management have been limited, and significant knowledge gaps remain, particularly fuel and treatment quantification. In general, the theory behind fuel treatments has lagged actual practice as implementation has preceded scientific understanding. Until the late twentieth century, fuel hazard reduction was considered incidental to forest management activities such as timber harvesting (exception: southern California and other shrubland ecosystems). Fuel treatment usage has expanded in response to devastating wildfires despite limited insights regarding effectiveness. Extant procedures for analyzing treatment efficacy (i.e., computer modeling, retrospective analyses of wildfires encountering treated areas, and experimentation) likewise suffer from analytical shortcomings. Fundamental questions related to efficacy remain, especially linkage to treatment objectives as affected by fire behavior, treatment intensity, and values at risk. Future research needs include a generalized,
\end{abstract}

This article is part of the Topical Collection on Fire Science and Management

Philip N. Omi

Philip.Omi@ColoState.edu

1 Colorado State University, Fort Collins, CO 80523, USA cohesive theory on the role of fuels in combustion dynamics, and improved effectiveness metrics at project and landscape scales.

Keywords Fuel treatment · Hazard reduction · Treatment effectiveness $\cdot$ Wildland combustion dynamics

\section{Introduction}

Imagine a crown fire roaring through a forest like a runaway train, slowing dramatically as it encounters a stand of trees where the fuels have been treated by fire or mechanical manipulation. The treated area provides a momentary respite in the fire's ruinous pathway, lasting only so long as the treated fuels moderate fire severity. As the fire passes beyond the leeward side of the treated area, the untreated fuels allow the fire to regain momentum and resume its damaging advance. This scenario, though eye-witnessed infrequently in real time, evidentially recurs across wildlands globally whenever wildfires encounter fuel treatment areas. Documentation for such encounters, including case studies, compendia, extant rationale, and theoretical underpinnings, are summarized below.

Wildland fuels have been manipulated for as long as humans have used and managed forests (e.g., logging, range, and wildlife habitat improvement activities). Over time, fuel profiles modulate across a landscape with natural disturbances, such as fire, erosion/sedimentation, floods, and wind events, interacting with climate to produce a dynamic mosaic of vegetation types with varying degrees of flammability. Conventional narratives suggest that fire suppression policies can accelerate fuel accumulations, especially in long-needled pine and dry, mixed conifer forests of the western, southwestern, and southeastern USA. Typically, these forests burned 
frequently with low severity but more recently have missed one to several fire returns due to exclusionary fire practices. Each missed fire return postpones the removal of understory plants, litter, and dead fuels while also allowing the growth of seedlings and saplings to form fuel ladders connecting surface to crown strata. An eventual catastrophe becomes unavoidable when too many fire returns are postponed, especially if prolonged drying and high winds accompany the inevitable ignition.

The conventional wisdom about fuels and fire exclusion has been reinforced emphatically in the USA during the twenty-first century, where the largest fires in state history have been recorded in Arizona, Colorado, Oregon, California, Texas, Oklahoma, Washington, and New Mexico. These incidents have spawned a variety of US federal reactionary responses (e.g., the National Fire Plan, Healthy Forests Restoration Act, and National Cohesive Wildland Fire Management Strategy, among others), which add to a litany of fuel treatment mandates stemming from episodic wildfire events during the latter half of the twentieth century. These reactions largely reinforce the notion that unmanaged or mis-managed fuel levels bear at least partial responsibility (along with climate) for the gravity of recent mega-fires.

A central postulate for the current discussion is that the theory and practice of fuel management are restricted by shortcomings in fuel and treatment quantification. As an immature science, fuel treatment metrics and measurement standards need refinement or are yet to be developed. Moreover, advancement in treatment practices is hindered by the absence of a coherent theory of fuel dynamics to inform fire behavior understanding. Thus, current fire spread models are unable to account for all significant heat transfers in treated vs. untreated fuels. Finally, despite a fairly lengthy time frame since fuel modification has been practiced, relatively little information is available on the payoffs from fuel treatment efforts. Potential benefits from fuel treatments are fairly intuitive and include the following: provide for firefighter safety through improved access/egress, including safety zones, facilitate opportunities to stop or slow wildfire growth or else improve prospects for managing unplanned ignitions for resource benefit, reduce the size and cost of unplanned ignitions, and, lastly, indirectly reduce burn area rehabilitation needs and costs, lower smoke emissions, and facilitate ecosystem resiliency.

Objectives for this paper include: (1) provide historical perspective, including previous practitioners and policy precedents, (2) summarize current fuel treatment practices in managed forests, focusing on the western and southeastern USA (where most treatment has been concentrated), (3) summarize theoretical understanding that informs practices, and (4) suggest areas of needed future emphasis.

\section{Historical Perspectives}

An actively flaming fire poses significant challenges to fire managers, not the least of which are firefighter and public safety, as well as damage to structures and natural resources, including watershed and air quality impacts. By large, North American wildland fire policies have been dominated by attempts to aggressively restrict forest burning motivated primarily from an endless progression of large, destructive wildfires that have occurred since European settlement. The mechanisms associated with large and costly wildfires are conceptually straightforward [1]: Flammable materials (fuels) are exposed to an intense heat source (firebrand) coincident with contributory weather and fuel conditions (fire danger). Reduction of large fire probability thus focuses on one or both of two strategies: (1) elimination or reduction of firebrand sources (risk management) or (2) removal or modification of fuels to reduce flammability during high or extreme fire danger conditions (hazard reduction).

The well-known Smokey Bear campaign ("Only You Can Prevent Forest Fires") represents a successful marketing strategy focusing on mitigating human-caused fire risks. Despite widespread popularity, its success is largely unquantifiable and unknown, especially since fire prevention/exclusion has contributed to unsustainable fuel hazards in some ecosystems. Interruption of historic fire cycles, especially in dry coniferous forests, has precluded periodic fire from clearing forest understories or regulating floral and faunal species diversity. Wildfire mitigation by fuel hazard reduction can be traced back to the "light burning controversy" of the early twentieth century. At that time, several timberland owners in northern California proposed that periodic, intentional forest burning was needed to clear the understory of hazardous fuels so that subsequent fires would burn less severely [2]. Most of their peers argued otherwise, recalling earlier fire episodes and expressing beliefs that fires could and should be excluded. The federal US Forest Service (USFS) partially resolved the debate over this controversial proposition with institution of its 10AM policy in 1935 [3], mandating nationwide aggressive suppression efforts that predominantly persist to this date. Even so, "light burning" advocates endure to this date, despite evidence that the practice is not appropriate for specific fuel types, such as southern California brushlands [4, 5]. The USFS eventually recognized regional needs for fire use to be integrated with fire suppression as part of cost-effective fire management [6]. Additional US federal policy revisions over time, including inferential recommendations, are noted in [7].

In part, the controversy over light burning arose due to the relative absence of fuel management precedents in the European style of forestry from which American practices were largely derived. American forestry practices were rooted in principles advanced by Bernhard Fernow (schooled in Prussia) and Gifford Pinchot (France), among others. Accordingly, 
most forests were managed for timber production; the assumption being that if soil and watersheds could be protected, then forested areas would supply a broad range of uses and values to the American public in perpetuity [8]. Fire was viewed as an external disturbance that could be excluded with sufficient technology and labor. Large fire years like 1871 (Wisconsin), 1902 (Pacific NW), and 1910 (Idaho and Montana) thus were considered preventable anomalies, traumatic for certain yet manageable. Fire exclusion was likewise practiced in other non-timbered wild areas, such as southern California with its expansive chaparral fuel beds or the Great Basin sagebrush (Artemisia tridentata)-dominated wildlands.

By contrast, the consensus among modern day fuel managers is that fire must be viewed as integral to managing some ecosystems, though certainly not all vegetation types. Moreover, practitioners are less averse to periodic light burns, in partial recognition of the ubiquity with which Native Americans once fired the forest [9]. Although periodic large fire episodes stimulated federal investigative interest in managing wildland vegetation [10-13], fuel management as a conceptual practice did not appear in US forestry textbooks until the mid-1970s [14]. Thereafter, wildland fire science academic programs (housed primarily in university and post-secondary forestry curricula) increasingly incorporated improved understanding of combustion dynamics as related to fuel treatments. With noted exceptions, government forestry research programs largely overlooked fuel treatment inquiries until institution of the Joint Fire Science Program (JFSP) in 1997 (www.firescience.gov). JFSP creation boosted fire research in general and fuel treatment science in specific, with particular investigations driven by manager needs. A federal policy review following the tragic South Canyon fire in 1994 had noted the inadequacy of extant fire research and spurred the creation of JFSP with four emphasis areas: (1) fuel inventory and mapping, (2) evaluation of fuel treatments, (3) scheduling of fuel treatments, and (4) monitoring and evaluation. JFSP has broadened since inception to incorporate additional subjects and regional manager science consortia.

US wildland fire research infrastructure prior to 1997 was largely vested within the experiment stations of the federal Forest Service, large national parks, and detached universities with academic programs in fire science. Moreover, relatively little scientific research was available internationally due to management emphasis on fire suppression (as opposed to fire use) outside US borders. Thus, relatively little fuels management research is conducted outside the USA.

Further, it is important to understand modern fuel management largely originated with North American forestry practices due partly to the vast public land domain encompassing ecosystems with a propensity for episodic fire outbreaks. The uniqueness of North American fire regimes, policy concerns, and size of the land base presents public land managers with exceptional fuels management challenges.

\section{Previous Practitioners and Policy Precedents}

Early practitioners played an important, mostly solitary, advocacy role for fuel treatments as an alternative to horrific losses from wildfire calamities. Though mostly anecdotal, their viewpoints established important precedents for treatment effectiveness, even absent data on actual performances. More recently, fire policy reviews following momentous fire seasons (e.g., 1994, 2000, 2004, and 2012) all point to the primacy of needed expansion in fuel treatment programs, despite fragmented evidence for treatments making a difference in subsequent wildfire behavior, costs, and losses.

Even though fire exclusionary policies were instituted with the USFS 10AM policy, detractive points of view persisted led by extant practices in the southern USA. Herman Chapman's studies of fire in longleaf pine (Pinus palustris) and Herbert Stoddard's investigations of fire and Bobwhite quail (Colinus virginianus) habitat are particularly noteworthy. Three heraldic pioneers (Harold Weaver, Harry Kallendar, and Harold Biswell) provided positive rationale, albeit mostly anecdotal, for the importance of prescribed fire in western forests [15].

Like the USA, most other nations have few early precedents for practicing fuel management, focusing instead on maintaining a highly reactionary response to wildfire incidents. Thus, most developed countries have sophisticated infrastructures for suppressing fires. In the USA, this infrastructure includes a complicated set of agreements between a variety of agencies spanning federal, state, and local jurisdictions, including private, non-governmental entities. US federal agencies cross multiple executive departments and bureaus, including Agriculture (Forest Service) and Interior (Bureau of Land Management, National Park Service, Fish and Wildlife Service, and Bureau of Indian Affairs), Defense, and Homeland Security (US Fire Administration). Moreover, federal agencies differ from state and municipal jurisdictions, such as CAL FIRE and Los Angeles County, including important policy distinctions in terms of both fuel management and fire suppression. With a dominant suppression culture, local jurisdictions have little incentive to develop a preventive infrastructure for managing fuels and, therefore, for fuel treatment research. Incentives for fuel treatment are similarly low globally, especially in nations without large public wildland domains or with hegemonic suppression philosophies. Democratic institutions such as free elections and public interest groups with strong environmental biases further complicate US management practices.

Objectives for fuels management have not changed much over the years and generally aim to achieve the above-stated benefits at least cost. Even so, documentation is scant that specific payoffs are actually realized. Arguably, wildfire encounters with areas where fuels have been manipulated provide the best evidence of fuel treatment effectiveness, but limited information is available here as well. Anecdotally, 
we know that, when possible, experienced fire bosses will herd a spreading wildfire toward recently burned areas, understanding that the altered fuel profiles in burned areas can favorably reduce combustion intensity or rate of energy release, thereby facilitating suppression efforts. A mosaic of lowered combustion intensities in turn provides more options for producing a distribution of favorable outcomes across a landscape or fireshed, such as reduced fire severity, structures protected $[16,17]$, or retention of desired faunal habitats. Furthermore, based on combustion physics, a fuel treatment area, much like a recently burned patch, should provide options to managers for herding fire growth during an ongoing incident. Even so, both fuel-treated areas and recent burns possess subsequent temporal thresholds beyond which suppression efforts are no longer facilitated.

Overall, little documentation exists for fuel treatment effectiveness, especially based on actual encounters with subsequent wildfires. Reasons for this scant coverage are elaborated below but generally include difficulties in timely isolation of the treatment effect from the myriad of other confounding influences, such as fire weather and management actions. With the possible exception of dry coniferous forests, the absence of concrete documentation contributes to confusion about fuel treatment effectiveness. Even in dry forests, the associated costs and benefits are poorly documented.

\section{Current Practices: a Summary}

Figure 1 conceptualizes fuel management as comprising two complementary land management aims: fire control and ecosystem maintenance/restoration. Fire control is facilitated through reducing fuel hazards in individual stands and through strategic placement of fuel breaks and treatment patches across a landscape. Restoration and/or maintenance treatments are required to sustain fire-prone ecosystems where historic fire cycles have been disrupted and fuel levels must be adjusted and maintained to cope with wildfire recurrence.

Fuel treatment practices of note include prescribed fire and mechanical manipulations such as thinning, crushing, and shredding or mastication $[18 \bullet \bullet, 19]$. Prescribed fire, or the intentional use of fire to achieve management objectives [20], is derived from long-standing traditions of woods burning in the southern USA. Mechanical treatments include the use of handcrews with chain saws and machinery developed to extract or manipulate forest biomass. Depending on forest condition and land management objective, a combination of prescribed fire and mechanical treatments may be required (Fig. 2). Thinning is an intermediate cutting or tending operation to adjust stand density, regulate species composition, or otherwise improve forest quality through the principles of silviculture [21].

Land uses affect fuel profiles and subsequent wildfire behavior, as do permanent fuel modifications such as fuel breaks and firebreaks $[22,23]$. These permanent strip installations across a landscape have been contrasted against smaller, strategically placed treatments or burn patches intended to effectively slow the spread of fires [24]. Ostensibly, some fuel manipulations add value by creating "shadows" of reduced fire severity alee of the treated area.

Table 1 summarizes various strategic alternatives for treatments, including advantages and disadvantages that must be evaluated alongside objectives and costs. For example, disposal on-site (e.g., broadcast or pile-burning) may accelerate natural processes such as biomass decomposition and nutrient cycling, but may raise concerns about air quality or risk of escape. Redistribution on-site (e.g., thin followed by lopping and scattering, mastication, or chipping) may reduce fuel bed depth and jackpots in an area but increase overall fuel continuity. A horizontally continuous fuel bed not only may be
Fig. 1 A fuel management organization chart, depicting the breakdown of fire control and ecosystem maintenance/ restoration aims into treatment types. Both aims require treatments that are sensitive environmentally, sustainable, and facilitate resilience to eventual wildfires

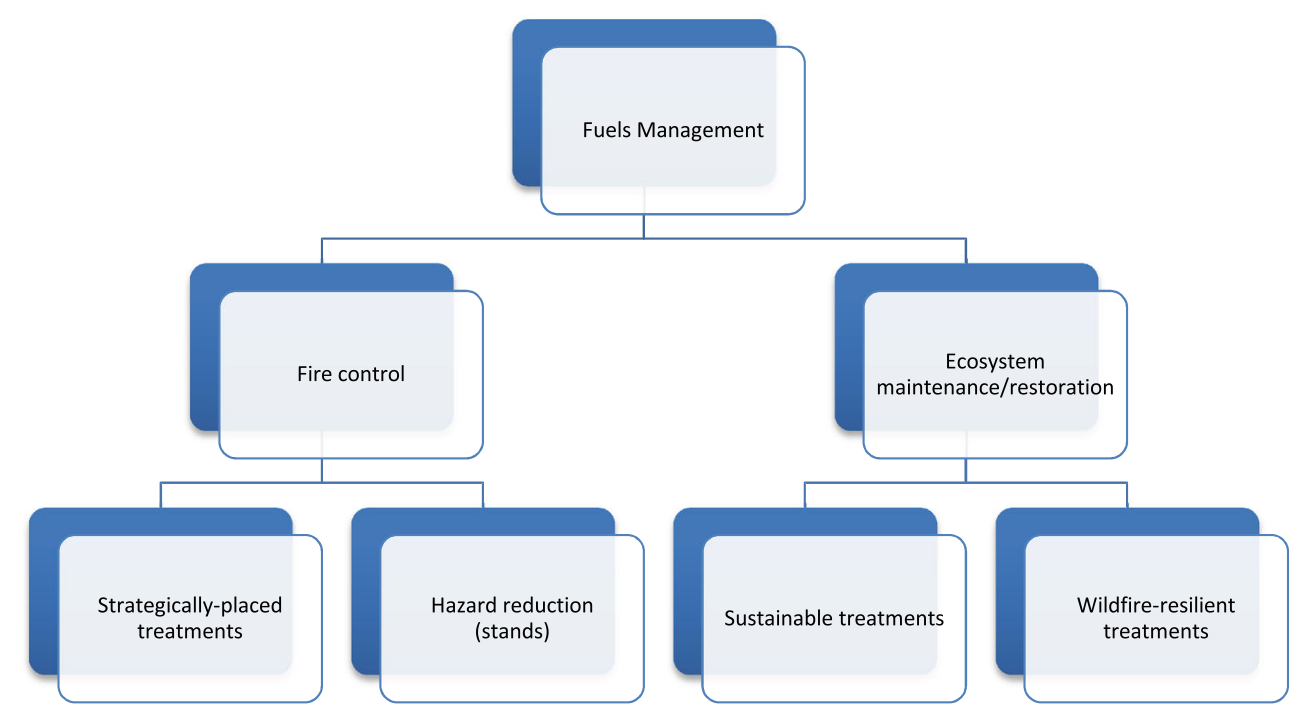



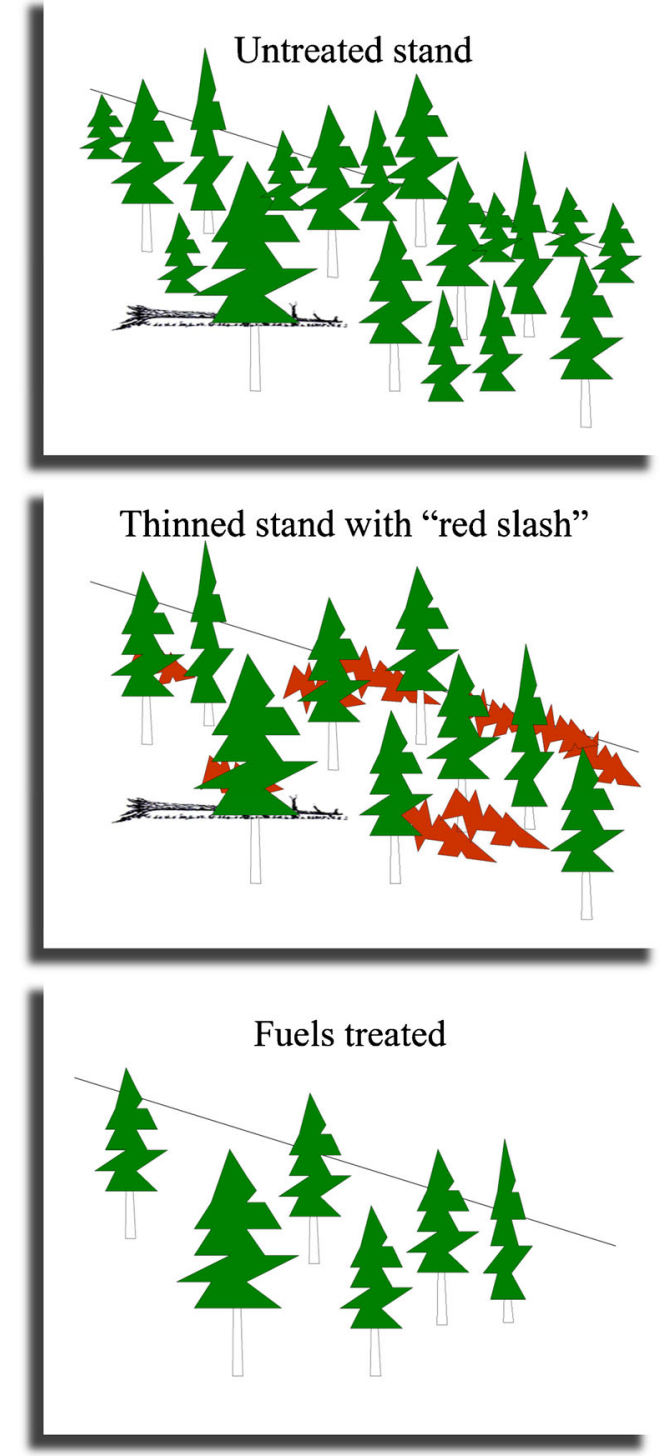

Fig. 2 A typical fuels treatment sequence involves reducing stand density by cutting small trees ("thinning from below"), followed by disposal of thinning slash, also known as "red slash" for the dessicated needles on cut trees. Fuels in the treated stand (bottom panel) can be maintained subsequently at desired levels with prescribed fire

desired for future broadcast burning but also may contribute to increased wildfire spread rates and severity. Also, chipped material left on-site may not decompose readily, depending on the status of soil carbon and nitrogen pools, among other forest influences on decomposition and plant growth [25].

Physical removal (using crews or mechanized equipment to transport fuels off-site) may lower potential fire behavior but can raise concerns about site disturbance or possible depletion of nutrient capital. Type conversion, say from shrub field to grassland, may reduce flammability but may raise concerns about introduced and/or invasive species. Isolation using fuel breaks, firebreaks, or greenbelts may effectively protect high-value areas or create useful fuel buffer zones for firefighter access/egress. However, the visual impact of reductions in basal area or stem numbers may not always be pleasing aesthetically. Practices such as chemical sprayings that defoliate/desiccate fuels and biological agents (e.g., goats and cows) are noted here for completeness though less frequently employed.

Historically, in the western USA, fuels have been manipulated in long-needled pine, e.g., ponderosa pine (Pinus ponderosa) and dry mixed conifer forests found in the Sierra Nevada, Cascade, and Rocky Mountain ranges, along with shrub lands and woodlands in southern California and the Great Basin, for example. These fuel types characterize most fire-prone ecosystems, primarily found in large tracts of public land in the western USA, although early precedents for prescribed fire were established on private lands in southern and southeastern yellow pine forests predominated by species such as longleaf pine and loblolly pine (Pinus taeda). Fuel treatments also are of interest in eastern forests, such as the central hardwood woodlands consisting of oak (Quercus spp.) and mixed hardwood pine assemblages. The northeastern USA is also characterized by large blocks of private land, but without the traditions of woods burning established in the south, although Native Americans reportedly used fire on the landscape prior to European settlement.

Lightning fire management in national parks presents a unique variant of fuel treatments that can also produce selfregulating, sustainable hazard reduction. Examples include Illilouette and Sugarloaf Valleys in Yosemite and Kings Canyon National Parks [26, 27••]. A similar program in Grand Canyon National Park essentially uses a herding strategy on ongoing fires, taking advantage of the lowered fire severities expected when fire spreads into recently burned areas, a practice reported earlier in southern California chaparral [28]. The national park programs use lightning ignitions to restore and sustain backcountry, dry mixed conifer ecosystems. By contrast, South African park managers use intentional ignitions to augment lightning fires for improving wildlife habitat in savannah fire regimes [29].

Federal agencies treated approximately 21 million hectares of US public lands during 2001-2013 [30], with Fig. 3 showing annual treatment averaging about 1.6 million ha. Most of the annual treatment area is concentrated in the southeastern and western USA, with prescribed fire as the predominant practice in the southeast while the west employs a combination of mechanical and fire treatments. The aggregate total area treated during this 13-year period represents about $7 \%$ of the 280 million ha land base administered by federal agencies [20] or less than $1 \%$ per annum. The federal treatment area does not include state and private lands, nor does it convey the unintended hazard reduction that might occur within wildfire perimeters.

By contrast, the 10-year average of area burned by wildfires is about 2.7 million ha [31], so wildfires encounter fuel- 
Table 1 Representative fuel treatment categories, including descriptive examples and advantages/disadvantages after [20]

\begin{tabular}{|c|c|c|c|}
\hline $\begin{array}{l}\text { Treatment } \\
\text { category }\end{array}$ & Example/description & Advantages & Disadvantages \\
\hline Disposal on-site & $\begin{array}{l}\text { Prescribed burning to achieve management } \\
\text { objectives under pre-specified } \\
\text { environmental conditions }\end{array}$ & $\begin{array}{l}\text { Mimics natural processes } \\
\quad \text { (i.e., fire, decomposition) }\end{array}$ & $\begin{array}{l}\text { Air quality, risk of escape, non-uniform } \\
\text { fuel reduction }\end{array}$ \\
\hline $\begin{array}{l}\text { Redistribution } \\
\text { on-site }\end{array}$ & Thin, masticate or lop-and-scatter debris & $\begin{array}{l}\text { Reduces fuel jackpots, especially } \\
\text { with slash disposal }\end{array}$ & $\begin{array}{l}\text { Resulting fuelbed may be more continuous } \\
\text { carbon/nitrogen ratios may be } \\
\text { unfavorable for plant growth }\end{array}$ \\
\hline Physical removal & $\begin{array}{l}\text { Yarding un-merchantable or unusable } \\
\text { material }\end{array}$ & $\begin{array}{l}\text { Materials removed may be used } \\
\text { (e.g., firewood, energy co-generation) }\end{array}$ & Possible site disturbance, nutrient depletion \\
\hline Type conversion & $\begin{array}{l}\text { Fuelbreaks/firebreaks change plant cover } \\
\text { from shrubs to grasses }\end{array}$ & $\begin{array}{l}\text { Reduces flammability (spread, } \\
\text { severity) by changing fuel type }\end{array}$ & $\begin{array}{l}\text { Invasive plants, chemical or biological } \\
\text { methods may be questionable }\end{array}$ \\
\hline Isolation & $\begin{array}{l}\text { Community fire protection creating } \\
\text { defensible spaces }\end{array}$ & $\begin{array}{l}\text { Protect high-value areas or provide } \\
\text { anchor points for incident } \\
\text { management }\end{array}$ & Landscape aesthetics may be compromised \\
\hline
\end{tabular}

treated areas only coincidentally. Western wildfires seem to be getting bigger in size, especially as indicated by the aforementioned records broken in the western states USA since the year 2000. Even though northeastern US fires are not trending larger, national totals for burned area are trending upwards along with suppression costs. With suppression costs taking up greater proportions of US federal land management budgets, agencies are forced into "borrowing" from other essential activities to cover fire-fighting expenses [32]. Does this indicate a failure in the fuels management program? Not necessarily, especially since wildfires encounter fuel treatments only by coincidence. In fact, larger burned areas may indicate that wildfires are performing more ecological work in terms of fuel abatement, especially in backcountry areas away from human developments. Moreover, the larger burn areas belie the increased complexity of incident management, including ecological effects and socio-political reactions, especially with recurring droughts and ostensible climatic changes.
However, the annual treatment levels depicted in Fig. 3 beg several questions, including: (1) How much fuel treatment is necessary?; (2) What are the payoffs from treatment?; and (3) How are lands prioritized for treatment? Arguably, the inability to answer these fundamental questions restricts implementation of fuel treatment practices. In reality, each question involves considerable uncertainty regarding climate, spatial patterns, costs, and returns.

Further, enormous treatment backlogs persist, including the area where fire returns have been skipped and lands where residual fuels (e.g., thinning slash) from treatment activities await reduction or removal. These backlog areas are found on government and private lands due in part to decades of attempted fire exclusionary practices but also insufficient attention to treating activity fuels. If and when these backlogs come under treatment regimes, then wildfires will become more manageable with less resource damage, with overall decreases in fire severity. Even then, wildfire-burned area
Fig. 3 Federal land area (hectares) treated to mitigate wildfire hazards in the USA, 2003-2013, after [30]

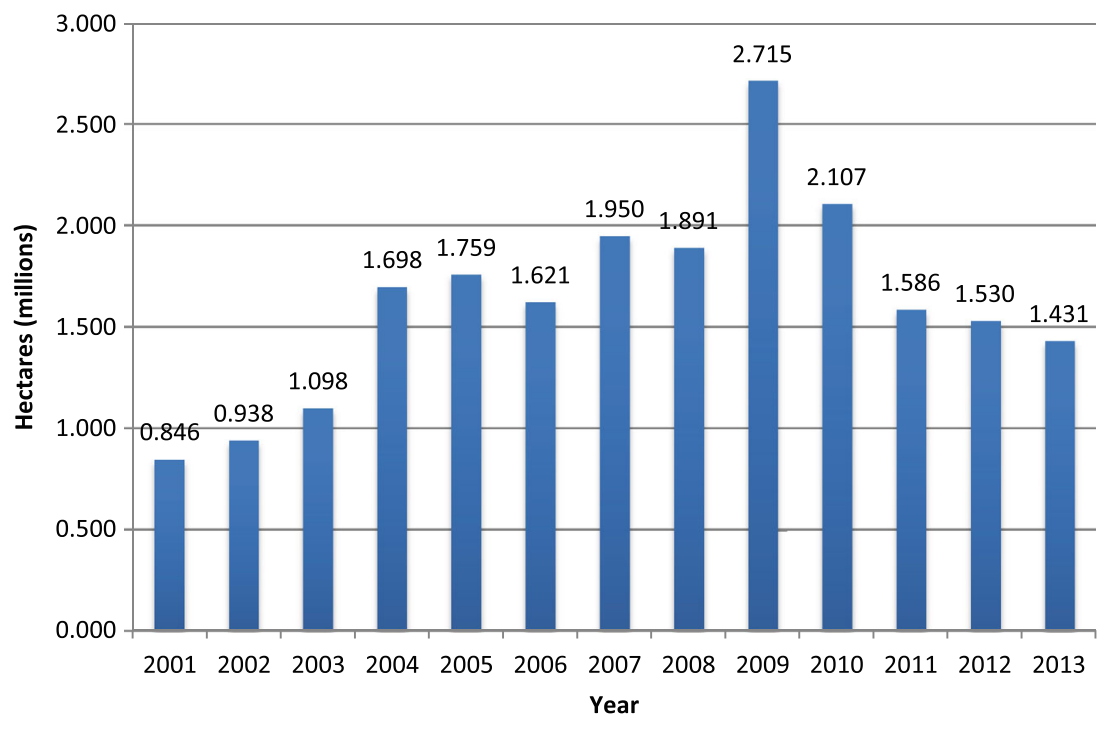


might not go down, especially since managed wildfires may be the most effective way to reduce fuel levels across landscapes. Further, total suppression costs may be higher than if fires are suppressed when small [33]. On the other hand, opportunity costs of aggressive fire suppression strategies in the short-term include the fuel buildups in areas from which fire is excluded.

As noted, fuel treatments span a considerable number of different options, including multiple fire uses and a myriad of mechanical manipulations. Likewise, the scale of treatments can vary spatially and temporally. The spatial scale encompasses a diversity of projects, from individual treatments sequenced in a forest stand to community wildfire defense plans in the urban interface, and/or fire and mechanical manipulations planned for entire landscapes or watersheds in a national forest. Federal and state agencies in the USA may plan for regional or larger scales over a time horizon that can span decades. The treatments themselves may vary from mechanical thinning and mastication to an almost-endless number of physical removal and prescribed fire combinations. Depending on objective, a fire treatment may be applied to maximize or minimize fuel consumption with a watchful eye on subsequent wildfires. A suite of treatments by prescribed and managed wildfires (i.e., of low to moderate severity) has been suggested for national forests in California [34].

Practitioners are beginning to realize the futility of suppressing all ignitions and of fuel treatments that perpetuate fire exclusion or that result in landscapes that still cannot be burned safely [35]. This includes recognition that wildland fires can be used to achieve resource benefits in some ecosystems. Smoke impacts from wild and prescribed fires will continue to be a concern (especially impacts on human safety and health), but must be weighed against even more formidable future smoke and carbon outcomes if fires are excluded. Also, there is growing recognition that reduction in eventual burned area is a poor indicator for assessing treatment success. Statements of treatment aims need to reflect more realistic objectives (i.e., $100 \%$ reduction in burned area is neither achievable nor desirable, but incremental improvements should be attainable in the survival of large trees following wildfire).

Methods for analyzing fuel treatment effectiveness include: experimentation, post facto analyses, gut logic, and computer modeling. Most studies and fuel treatment planning documents (i.e., for justifying treatments proposed for an area) rely on one or more of these analytical procedures. Certainly, the early practitioners relied more on gut logic than anything else. More recent studies have relied to varying degrees on all these alternatives. Studies involving actual field measurements are increasingly more available.

Rigorous scientific experiments (i.e., randomized, statistically blocked treatments vs. control groups) for assessing fuel treatment effectiveness are quite limited due to societal constraints against the intentional setting of wildfires for comparing treated vs. untreated areas. The International Crown Fire Modelling Experiment [36] provides a noteworthy anomaly conducted as it was in the boreal forests of the Northwest Territories, Canada. Even so, differences in vegetation/fuel type characteristics restrict the comparability of results elsewhere, i.e., with forests in the western and southern USA. Notwithstanding this example, the challenge is to ascertain fuel treatment impacts on fire behavior and effects compared to the untreated condition, much as pharmaceutical dosages are tested against placebos. Before and after comparisons of treated vs. untreated areas during an ongoing wildfire might be possible using remote-sensing devices but have not advanced beyond preliminary trials.

Quantitative information is scarce on fuel treatment effectiveness as noted in a meta-analysis of treatment (prescribed fire, thinning, and combinations thereof) effects on fire severity [37•]. For the fires studied (i.e., in long-needle pine and dry mixed conifer forests), the most effective treatments were those that complement ecological restoration objectives, such as by removal of small trees (also called "thinning from below") from ecosystems historically subjected to frequent fires. Their studies confirm that treatments have been successful in reducing wildfire severity, particularly when prescribed fire is incorporated no longer than 10 years previously, although treatment longevity varies by ecosystem. Moreover, until residual activity fuels are disposed, they largely offset much of the hazard reduction benefit achieved from opening the canopy. While follow-up slash treatment may be intended generally, untreated slash is encountered by large wildfires with surprising frequency.

Other post facto or retrospective analyses of wildfire-fuel treatment interactions include case studies for the Cone Fire in northern California [38] for central Idaho wildfires during 2007 [39, 40] and for California national forests [41]. These investigations generally support the effectiveness of forest thinning followed by some form of slash removal for reducing subsequent wildfire behavior. Similarly, satellite imagery (differenced normalized burn ratio, dNBR) and spatial statistics detect lower burn severities in fuel-treated areas for three wildfires [42]. Further, fuel treatments may promote ecological resilience to severe wildfires in dry, mixed conifer stands of the western USA [43••]. The information from case studies thus provides an important foundation for understanding fuel treatment effects.

Post-wildfire comparisons of fire severity in treated areas against similar control plots lack the statistical power of controlled experiments but may represent the most realistic alternative for analyzing the performance of treatments. Further, smaller scale-prescribed fire field trials to establish effectiveness provide limited understanding of how fuel treatments will perform during wildfires. Still, the hope is that, over time, a sufficient track record can be compiled so that a "treatment effect" can be established by the overall preponderance of 
evidence, much like the eventual link established between cigarettes and cancer (or greenhouse gases and climate change). As the science advances, the logic of treating fuels to reduce wildfire costs and damages likewise becomes more ingrained.

\section{Theory Underlying Fuels Management: a Summary}

One way of thinking about fuel treatments and wildland fire is to conceptualize the growth of a hypothetical wildfire over time (Fig. 4). Often, a fire's growth rate is greater during active flaming as compared to either incipient or latter stages of fire growth. During active flaming, newly ignited areas coalesce and growth rates exceed extinction in those pockets where the fire is slowing down or going out. Eventually, a fire's overall growth rate slows due to environmental dampers (such as atmospheric humidity), physical restrictions (e.g., water bodies, rock outcrops, fuels modified by previous treatment/recent wildfires), and suppression activities (crews and equipment). Areas of new ignitions become isolated and relatively infrequent compared to the total burn area, as growth diminishes and total fire area plateaus at its maximum. To date, the most pronounced effects and greatest promise of fuel treatments include reductions in a fire's severity during active flaming. Reductions in severity during active flaming in turn lessen the fire's acceleration and eventual extent (i.e., slope and height of zone B in Fig. 4). Severity reductions during a fire's initial stages (zone A) are realized only if ignition occurs in an area treated previously.

Figure 4 distinguishes between the hypothetical wildfire and another fire burning under identical environmental conditions but encountering an area where the fuels have been treated previously. With fire size as one proxy for wildfire impacts (an imperfect yet reasonable indicator), then the effectiveness of fuel treatment can be conceptualized as the distinction between the no-treatment and treatment curves (i.e., reduction in

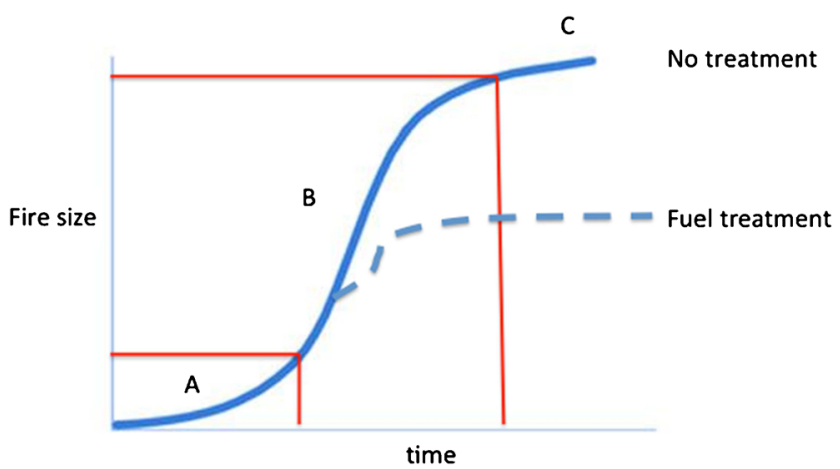

Fig. 4 Stages in fire growth: fire initiation $(A)$, fire acceleration and growth $(B)$, and fire growth taper and extinction $(C)$. Fuel treatments are especially critical in mitigating fire growth in stage B. The location of the treatment branch will depend on the ongoing fire's travel distance to the treated area(s); slope will depend on post-treatment fuel availability. The sigmoid shape of the no treatment growth curve is from [44] final fire area). Presumably, the treatment reduces available fuel (i.e., the quantity of fuel that actually burns [45]), thereby lowering fire severity and permitting crew and equipment activities to limit the fire's growth and restrict eventual burn area. Moreover, the greatest payoffs from fuel treatment will be realized as the encounter zone for potentially damaging fires shifts from zone B to zone A (Fig. 4).

The logic and theory of fuel treatments are often based on rudimentary knowledge of fuel/fire dynamics. Early US practitioners relied on subjective observations and, later, changes to qualitative indices (e.g., low, moderate, and high resistance to control). Conventional wisdom with access to more quantitative estimates (e.g., projected fuel impacts on spread rate and fireline intensity) has informed several compendia for western coniferous forests [46-50]. These provide useful guidance for fuel treatments, including impacts on forest structure and ecosystem dynamics supporting the principles and sequencing of fuel treatments summarized in Table 2 .

Thinning regimes for sustaining fuel levels in even-aged forests are contrasted in [51]. The sequencing of priorities embodied in Table 2 emphasizes the reduction of surface fuels and the retention of the largest trees in a stand, while recognizing the importance of opening the canopy in order to optimize the benefits of hazard reduction. Theoretically, reduction of fine (dead and live) surface fuels reduces fire intensity and flame lengths. Moreover, reducing canopy fuels and eliminating ladder fuels via thinning will decrease the probability that a crown fire will initiate and spread [52]. Mechanical thinning may be initially required where crown fire hazard has become so high as to preclude initial entry with prescribed fire. The most effective thinning treatments are those that produce substantial changes to canopy fuels, shift the diameter distribution toward larger trees, and are followed by broadcast burning or other methods of slash disposal [37•].

While the logic behind fuel treatments is straightforward, the theory is piece meal, reflecting the disjointedness of fire behavior knowledge, among other contributors. Questionable modeling linkages/assumptions and data sources confound analyses. For example, silviculturists have long employed thinning as an intermediate cutting or tending operation to regulate forest growth by adjusting stand density [21]. Limited attention had been directed to calculating increments in fuel hazard resulting from the addition of thinning slash (coarse woody debris plus fallen tree crowns) to surface fuels on-site, with and without treatment. Further, treatments can actually increase available fuel as dead surface slash or masticated debris desiccates, whereas much of the woody biomass likely would have been unavailable as standing, living vegetation. Computerized programs can make some of the calculations, but fuel inputs require user sophistication about internal mathematical relationships. In the USA, stylized fuel models can be selected [53,54] or customized [55] to permit fire behavior calculations following [56] essentially a radiation-based fire 
Table 2 Principles and appropriate sequencing of thinning a forest stand to increase resilience to fire, i.e., "thinning from below" after [51]

\begin{tabular}{llll}
\hline Principle & Effect & Advantage & Concerns \\
\hline 1. Reduce surface fuels & Reduces potential flame length & $\begin{array}{c}\text { Facilitates fire control; less torching; } \\
\text { reduced crown fire initiation/spread } \\
\text { 2. Increase height to live canopy }\end{array}$ & $\begin{array}{c}\text { Less surface disturbance with } \\
\text { prescribed fire than other techniques } \\
\text { Opens understory; may allow surface } \\
\text { wind to increase }\end{array}$ \\
$\begin{array}{l}\text { 3. Decrease crown density } \\
\text { initiate torching } \\
\text { Makes tree-to-tree crown fire } \\
\text { less probable }\end{array}$ & Reduces crown fire potential & $\begin{array}{c}\text { Surface wind may increase and surface } \\
\text { fuels may be drier }\end{array}$ \\
$\begin{array}{l}\text { 4. Keep bigger trees of } \\
\text { fire-resistant species }\end{array}$ & $\begin{array}{c}\text { Less mortality for same fire } \\
\text { intensity }\end{array}$ & Generally restores historic structure & $\begin{array}{c}\text { Less economical; may keep trees at } \\
\text { risk of insect attack }\end{array}$ \\
\hline
\end{tabular}

spread theory. However, doing so omits important convective heat transfers and relies on the integrity of surface area relationships specified internally within the computerized algorithms. Systematic fuel inventory techniques $[57,58]$ provide estimates for fuel loads that are inconsistent or insufficient for driving fire behavior predictions. Likewise, LANDFIRE [59] satellite-based fuel mapping estimates are subject to error when compared to field conditions [60].

Figure 5 provides a generalized schematic for interpreting fuel treatments in terms of linkages between fuel profiles, fire behavior, and subsequent fire effects. External influences, such as weather and moisture regimes, influence the role of fuels during combustion, as evidenced by various fire behavior indicators (most of which are altered by the type and timing of fuel treatment). Fire adaptations and moisture regimes in turn influence a myriad of short- and long-term fire effects, including floral/faunal, and broader impacts. Eventually, the cycle resets itself depending on plant reproductive strategies, post-fire climate and moisture regimes, and other influences on fuel accretion. Arguably, the ecological linkages
Fig. 5 A schematic representation of a typical fuel treatment regime, showing linkages between representative descriptors for a fuel profile, fire behavior, and fire effects including important external influences and feedbacks. Fuel treatments affect the fuel profile and consequent fire behavior/ effects

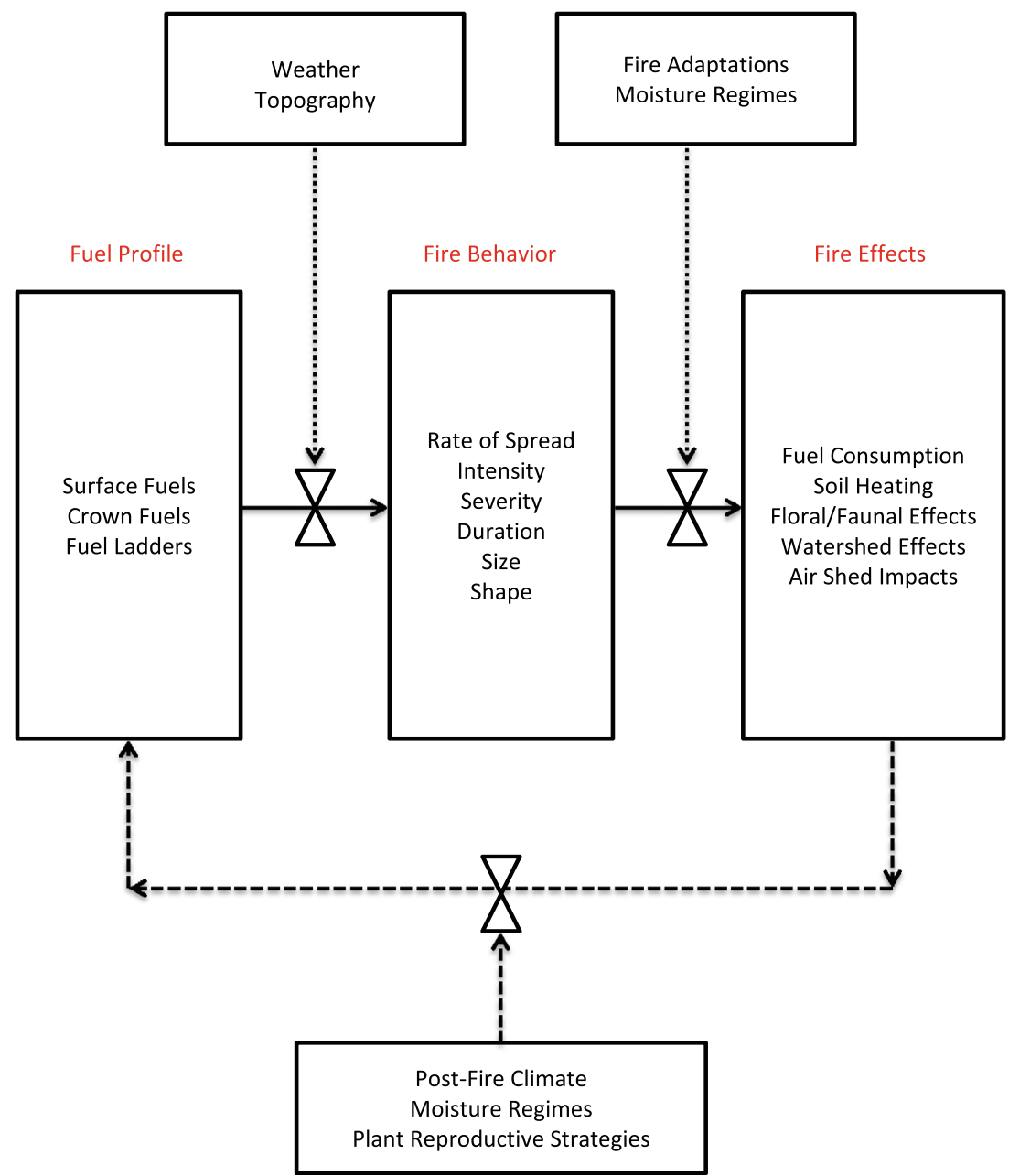


embodied in the schematic are even more fragmented than the fuel-fire behavior disjoints described above.

Treatments require manipulation of vegetation, possibly disrupting habitat, soil, air, and water resources. For example, controlled burns may displace fauna that seek shelter in coarse woody debris piles unless substitute habitat is readily available. Fire also can remove vegetation and root structures that hold soils to inclined hill slopes, above or adjacent to streams and reservoirs. Thus, treatments that remove vegetation can lead to soil erosion and water pollution episodes if implemented inappropriately. Soil and vegetation disturbances accompanying treatment also can facilitate establishment of noxious plants. Further, smoke from prescribed fires can be dangerous to public safety and severely disrupt commercial relations in an area.

Some of these impacts may be immediate (such as mechanical thinnings that remove stems and forest cover), while others may be subtle or nuanced, and not appear for some time (e.g., invasive plants that show up months to years after forest and rangelands burn). Other effects may be hidden from view, such as soil heating damage to sensitive feeder root systems of dominant trees. The economic, effectiveness, and ecological impacts from fire and fire surrogate treatments in dry, mixed conifer forests of the western and eastern USA confirm that multiple entries are required to sustain resistance against stand-replacing wildfires [61]. Treatments aimed at hazard reduction in dry forests are typically associated with few unintended consequences, producing mostly transient impacts on vegetation, soils, wildlife, water, bark beetles, and carbon sequestration $[62 \bullet \cdot]$. Moreover, the transiency of treatment effects on hazard reduction point to the importance of maintenance after initial entry, fine-tuned as needed in response to ongoing climate changes. Also, the initial entry and maintenance phases for ecological restoration objectives may vary considerably in terms of treatment type and desired outcomes. These notions reinforce concepts such as intelligent tinkering and saving all pieces in land conservation manipulations [63]. Thus, treatment impacts need to be identified, then carefully monitored and evaluated over time, especially in areas not previously studied, or where extant investigations report ambivalent or contradictory outcomes.

Fuel treatments do not stop individual fires from spreading and are not a panacea for dealing with wildfire issues arising from combustion effects, especially at the scale of current implementation that focuses primarily on the treatment of smaller areas, mostly individual stands. Moreover, expanding treatments to a landscape, region, or nation is fraught with implementation difficulties, especially because of the scale of treatments required and ecological concerns with fragmentation and biodiversity [64], among numerous other technological and theoretical concerns. Treatments do not only provide options for managing individual incidents, but they also may not be appropriate for all vegetation types, including those that burn infrequently with over-story crowns or shrubs fully engaged. Arguments can be made pro and con for some types, including southern California chaparral, lodgepole pine (Pinus contorta), jack pine (Pinus banksiana), and some boreal forests. Invasive plants may become a problem in some treated areas, for example Great Basin sagebrush lands where cheatgrass (Bromus tectorum) becomes established following prescribed burns. Non-native plant species also can be introduced where fuel treatments are applied, although wildfire and subsequent seeding efforts may promote greater plant invasions $[65,66]$.

Treatment practices vary by vegetation, slope, and elevation zones, with reliance on mechanical treatments and limited fire use around urban areas, but increasing reliance on prescribed fire through forested multiple use and wilderness areas. Treatment effects of concern span a diverse range of hazard reduction and ecosystem impacts, affecting the sustainability of any treatment regime. Other issues include physical results from initial and maintenance re-entries to short- and long-term effects on sustainable vegetation, soil, water, air quality, and carbon resources.

At times, fuel treatments can seem to increase fire hazard. When stands are thinned, more sunlight, water, and nutrients are available, feeding new growth of grasses and plants, which increases the surface fuels [67]. Woody debris left on-site after treatment becomes available for combustion, not only increasing flammability but also adding to increased plant injury and mortality during smouldering. Thinning also lets more wind enter the stand, a danger if a wildfire occurs [68]. Increases in fire spread rate and severity thus become possible, with magnitude dependent in part on treatment type and time since treatment, concomitant with fire weather influences. Increases in fire hazard also occur when live woody stems are converted to standing dead fuels (e.g., in brush fields, persisting until dead stems fall over or are masticated). Moreover, much information about treatment effectiveness results from modeling simulations, especially investigations at landscape scales, none of which have been validated under experimentally controlled conditions in the field.

Thus, fuel treatments are often misunderstood and can be confusing. For example, the lay public may have difficulty understanding that a treated area may slow but not stop an oncoming wildfire. Further treatments may not be appropriate for all ecosystems. Even more difficult may be the notion that the creation of fire-safe forests will require fuel manipulation using fire as a tool. Generally speaking, a low-intensity fire imparts a more nuanced impact on flammability than mechanical treatments (or severe wildfire), providing a temporary fire-proofing that may persist for up to 10 years in western forests $[27 \bullet \bullet, 37 \bullet, 68]$. Even shorter treatment longevities may characterize ecosystems, e.g., grass/shrub assemblages, where plant succession results in fine fuel accumulations shortly after treatment. Effective life of combined treatments (e.g., 
mechanical plus fire) will depend on a variety of site and environmental influences, with earlier maintenance required in more productive ecosystems.

Fuel treatments will not make much difference in the increasing wildfire trends noted previously until and unless greater proportions of combustible landscapes come under treatment regimes, including initial and maintenance entries using fire. Committed focus on areas with high values at risk will help in the interim. Even so, uncertainties in the theory of fuels management will persist because of an inability to scientifically specify all explanatory variables associated with treatments and effects. Others remain a legacy of theory lagging practices as described below.

Much of the uncertainty about treatments is because formal theory has not kept pace with practice. Notwithstanding a steady increase in publications about fuel treatments [37•] and models [69], practitioners have implemented treatments, often without scientific justification. In essence, fuel management researchers have played "catch up" to funding thrown after national fire crises, most notably in beefing up suppression readiness. Also, research budgets are lower and have less funding flexibility than responses to national emergencies.

Linkages among fuel dynamics, fire behavior, and consequent fire effects are poorly understood or may be fraught with unproven assumptions. Computerized simulations of fuel dynamics within a stand and across a landscape not only provide insights in some instances but also may suggest unrealistic levels of knowledge about cause-effect mechanisms or unjustified senses of comprehension, especially in the absence of field verification. At best, some landscape-scale simulations incrementally advance theoretical understanding by providing testable hypotheses informing future experimental design and data analysis.

Ironically, the theory behind landscape-scale fuel treatments is developing faster than practice, relying on computerized simulations that can overlook implementation difficulties, like budgets, land easements, and inter-agency cooperation. Table 3 lists examples of landscape-scale studies including geographic coverage, effectiveness metrics, and modeling approaches employed. Arguably, wildfire severity in treated vs. untreated areas should provide an empirical foundation (or at least a mental backstop) for reinforcing computerized predictions. Ground-truthing is limited, so the reliability of computerized predictions is unknown for studies listed in Table 3 .

Improvements in computer processing capability have facilitated investigations into landscape-scale fuel treatment effects (e.g., [76]), despite reliance on propagation models with limited capability for incorporating fire and fuel dynamics. Interesting results ensue, but with unknown truth value since the inferences are from models or simulation only. For example, LANDIS [82] simulations link together several models with unknown error propagation consequences. There are numerous analytical difficulties associated with carrying out such investigations, including reliance on fire spread processors with limited capability to model surface and crown fire transitions accurately. Further, all landscape-scale analyses rely on computerized models and/or remotely sensed signals or databases with limited field verification. Physics-based spread

Table 3 Representative examples of landscape-scale fuel treatment studies, including geographic coverage, effectiveness measures, and models used

\begin{tabular}{llll}
\hline Citation & Spatial/geographic coverage & Effectiveness measure(s) employed & Predominant model(s) relied upon \\
\hline$[70]$ & N. China boreal forest & $\Delta$ BP, fire extent, intensity & LANDIS, FARSITE \\
{$[71]$} & 14 large wildfires in 9 states, USA & $\Delta$ BP, fire extent & FARSITE \\
{$[72]$} & Dry forests western US & $\Delta$ fire type, TI & FFE-FVS \\
{$[73]$} & Sierra Nevada Mountains, California & $\Delta$ potential fire severity & LANDIS-II \\
{$[74]$} & Blue Mountains, E. Oregon & $\Delta$ BP, $\tau$ & ArcFuels, FFE-FVS, MTT \\
{$[42]$} & 3 wildfires, western USA & Fuel treatment $\beta$ & dNBR, LANDFIRE \\
{$[75]$} & S. Cascade Range, California & $\Delta$ area burned, potential crown fire activity & FARSITE \\
{$[76]$} & Sanders County, MT; Stanislaus NF, CA; & $\Delta$ spread rate, fire extent, BP & FVS, MTT, LANDFIRE \\
{$[77,78]$} & Blue Mountains SE WA & $\Delta$ BP, MTT & ArcFuels \\
{$[79]$} & S. Utah C. Oregon forests & $\Delta$ flame length, fireline intensity, crown fire & FARSITE, FlamMap \\
& & activity class &
\end{tabular}

$\Delta=$ change in predicted wildfire indicator(s), e.g., burn probability (BP), in treated vs. untreated pixelated areas, $\beta=$ regression coefficient, fire type $\epsilon$ \{surface, torching, crown $\}$, potential fire severity $=\mathrm{f}$ (crown-fraction burned, rate of spread) after [80], $\tau=$ wildfire mortality of large trees $=\mathrm{f}(\mathrm{flame}$ length)

TI torching index [81], LANDIS Landscape Disturbance and Succession Model [82], FARSITE Fire Area Simulator [83], FFE-FVS Fire and Fuels Extension to the Forest Vegetation Simulator [84], ArcFuels ArcGIS Interface for Fuel Treatment Planning and Wildfire Risk Assessment [85], MTT minimum travel time [86], $d N B R$ differenced normalized burn ratio algorithm [87], LANDFIRE Landscape Fire and Resource Management Planning [59], FlamMap fire behavior mapping and analysis system [88] 
models(e.g., $[89,90])$ show promise for improving the integrity of spread estimates but have not been extensively tested or evaluated for use in analyzing fuel treatments [91].

The role of fuels in current fire behavior models is incompletely understood, and the fire models themselves are incapable of accounting for all significant phenomena influencing fire propagation, especially under extreme burning conditions (e.g., crowning and spotting), thereby clouding pathways for understanding fire effects. Despite these imperfections, linking these models can be useful for planning purposes (e.g., the Interagency Fuel Treatment Decision Support System; see www.frames.gov/iftdss), although users are not often made aware of the required leaps in theory, including consequences. Sole reliance on such modeling efforts, especially for analyzing treated vs. untreated comparisons, may lead to spurious conclusions especially where model assumptions are not met or where ecological outcomes are not linked to fire severity indicators.

To sum up, most evidence for treatment effectiveness is limited, incomplete, and often anecdotal. The absence of a unified fire behavior-fuel treatment theory and limited quantitative evidence restricts the analyst's ability to show reliable expected outcomes, including returns from planned investments. Managers and planners likewise may have difficulty demonstrating accountability for the expenditure of public funds to reduce fuel hazards. Moreover, fire policy statements should more accurately reflect realities about the role of fire in the environment.

\section{Areas of Future Emphasis}

Improvements in the theory and practice of fuels management will require a multi-pronged approach to understanding the role of fire in wildlands as well as improved grasp of the unique niche occupied by fuels treatment within the broader rubric of fire and land management. In addition to budgetary stability, a critical piece of the puzzle involves improved understanding of the dynamic role of fuels in fire spread, severity, and growth, which in turn provides linkages to fire effects (both short- and long-term) at project and landscape scales. However, even more important may be policy shifts recognizing the essential role of wildland fire in sustaining fire-adapted ecosystems.

In addition to fuel treatment effects on future wildfire severity, improved understanding is needed of linkages between fire's physical changes and resultant biological, ecological, and socio-economic consequences. Fuel treatment economics can provide a template for a comprehensive analysis [92], especially where both monetary and non-monetary impacts can be arrayed. Fuel treatment economics also may provide insights into how best to contend over time with existing backlogs in necessary treatments as well as fuel treatment-fire suppression tradeoffs that must be considered in evaluating treatment efficiency. Also, since government entities will likely be involved in treatment implementation on many lands, public trust, and acceptance [93] are critical.

Table 4 provides a list of important themes requiring future attention, with focus on fuel treatments, treatment effects, and modeling. The list is based in part on interactions with managers and scientists in focused study groups [94]. The emphasis on metrics or measurement standards reflects the difficulties in quantifying treatment effects, including productivity. Modeling needs include a philosophical re-set so that models are used more as tools for thinking, rather than creating separate realities. Essentially, the need for improved metrics or measurement standards underlies all the important themes in Table 4, emphasizing the need for the fuel treatment quantification so essential for advancing understanding.

Improved measurement standards would also help agencies demonstrate accountability to stakeholders for funds expended (investment costs) and subsequent effects. The US Government Accounting Office has noted the need for improved measures of fuel treatment effectiveness to gauge reductions in risk and to allocate funds among competing projects based on cost-effectiveness $[95,96]$. Any measure must start with verifiable estimates of the performance where wildfires meet fuel treatments, such as in the case studies summarized here. Changes in wildfire severity due to fuel modifications thus provide an important starting point for assessing fuel treatment effectiveness, but more is needed. For example, changes due to treatment in the area of distribution of wildfire severity will need to be integrated with additional socioeconomic and ecological metrics that provide a more comprehensive view toward overall changes in risk and hazard.

Strategies that incorporate low-severity wildfires across large geographic areas may become increasingly appropriate over the long term, especially in fire-adapted ecosystems where public safety is not compromised and the flora/fauna depends on fire. This will require improved understanding of landscape treatment effects, including distinctions with and without fire, as well as providing managers with the policy latitudes on large and mega-fires. Further, managers will need to specify objectives clearly including metrics or measurement standards for demonstrating successful attainment.

\section{Importance of Effectiveness Measures}

Assessing the efficacy of fuel treatments is complicated, although effect on subsequent wildfire severity is fundamental to any analysis. Moreover, an understanding of fire behavior is essential for assessing fuel treatment effectiveness, not only in terms of comparing wildfire effects in treated (versus untreated) areas but also in terms of predicting how an installed treatment will perform before a subsequent wildfire occurs, 
Table 4 Recommended research foci for improving understanding related to fuel treatments, effects, and modeling after [94]

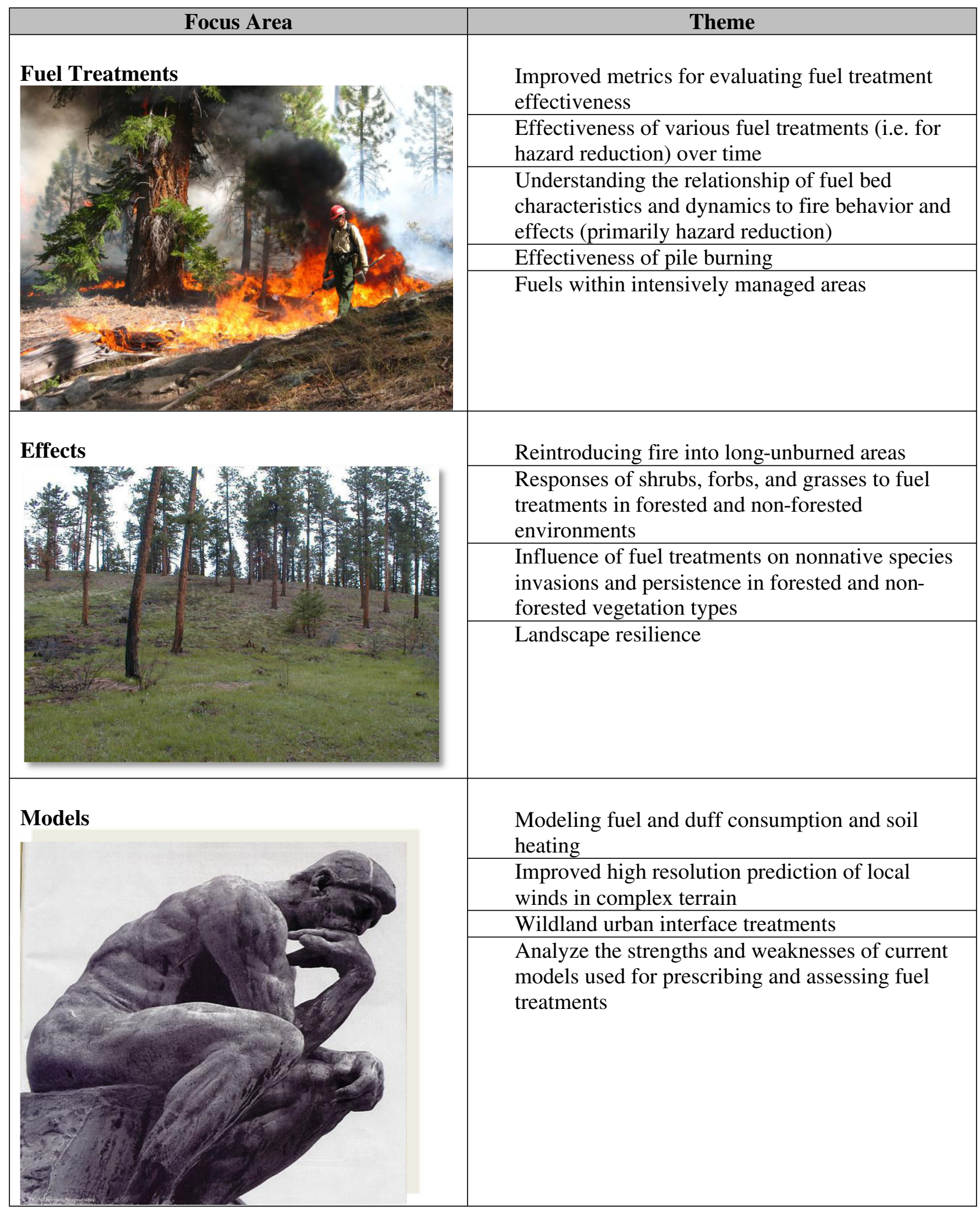

Photo credits: Brent Skaggs, Philip Omi, Philip Omi

including eventual ecosystem effects. Ideally, the notion of effectiveness should apply to the performance of the treatment installation in relation to the land management objectives for the area, including but not restricted to future wildfire effects 
on extant natural and developed resources. Thus, contributions to ecosystem sustainability, wildlife habitat, or other resources are relevant to the calculus, as well as associated economic and social costs, including those associated with the changed stream of suppression costs and losses in treated areas. Intuitively, suppression costs and losses should be lessened in areas where fuels have been treated. However, some of these estimates may be analytically difficult to calculate, especially where an entire landscape is only partially treated or where social costs can only be indirectly inferred, for example. Pragmatically, we tend to restrict focus to performance during a subsequent wildfire event, particularly to see if a treated area has contributed to reduced fire severity in and adjacent to the treatment area. Even so, as techniques and technology allow perhaps, we can begin to consider more inclusive aspects of treatment effectiveness.

Although fuels have been managed for a fairly long time period, fuel treatment success is not well-documented in most ecosystems (exception: long-needled pine forests). Once installed, a treatment may or may not be tested by subsequent wildfire, sometimes casting doubt upon the efficacy of the fuel modification. Arguably, treatments improve forest health even in the absence of a wildfire event, e.g., incremental increase in sustainability due to prescribed fire and/or improved structural changes due to thinning of understory and ladder fuels. For example, prescribed fire may be essential in fire-prone ecosystems where biodiversity or endangered species depend on fire. Assessments can be controversial and poorly understood, whether from the analysis of proposed treatment alternatives for an area, or with respect to the performance evaluation of existing treated areas during a wildfire event. Important challenges include the reliance, of necessity, on findings from nonexperimental studies. Further, analysis of burn patterns on eventual wildfires may require judgments about whether fuel manipulations actually worked. For example, a fire may burn benignly in a sub-standard treatment area due to high ambient fuel moistures. Also, high winds can blow a wildfire through an area that has been otherwise treated successfully. Statisticians refer to these respectively as instances of type I and type II errors in assessing hypothesized treatment performance.

Ultimately, decision-makers would like to know specific, quantitative relationships between investment costs and returns, in other words the productivity of treatments. In such cases, estimates for changes in fire severity/growth in treated vs. untreated area are essential for assessing productivity. Where available, these estimates provide the "holy grail" of interest to managers and policymakers (also certain publics) required for more meaningful indicators such as loss of human life and property.

Even so, transforming the fire behavior changes from fuels treatment into future reductions in suppression costs (or resource damage, or possibly, resource improvements) is easier said than done. Essentially, it requires knowledge of the production function for fuel treatments [97] relating returns (e.g., reductions in suppression costs and net value changes) to input (or treatment costs). Realistically, suppression cost savings and resource impacts (costs and damages) are difficult to estimate, especially since a wildfire ignition may or may not occur during the useful life of a treatment. In reality, some publics and policymakers would prefer simplistic answers (i.e., bang for the buck!) rather than academic explanations about the complexity of solutions.

\section{Conclusions}

Surprisingly, few breakthroughs have occurred in the theory and practice of fuels management during the past 5 years. Improved databases and sophisticated computers permit more complex simulations, but fundamental treatment effect metrics are lacking and new knowledge about treatment effectiveness is sparse. Radical increases in the cumulative area treated will be required to serve societal prerogatives, with concurrent attention to human values at risk, along with improvements in treatment monitoring practices (i.e., focusing on measures that are important to public well-being). Shifts in agency willpower may be most important.

Ironic as it may sound, we have known for some time that sustainable and resilient forests are those that can be burned safely. Forests in which periodic fire has been withdrawn may eventually burn with unacceptable severity, especially in a warming climate. Frequent, low-to-moderate severity fires may be the most effective fuel treatment for ensuring forest sustainability and resilience. When we forego the treating of fuels, we essentially accept the eventuality of the unmanageable mega-fires that have to date been so problematic. Moreover, fuel treatment may provide the only feasible buffers against future undesired effects due to climate change, insect and disease epidemics, and other ecosystem stressors, especially in western and southeastern ecosystems (less applicable in the northeastern USA).

Estimates for measuring the productivity of treatment outcomes are complicated, but should be one of the highest priorities for fuel management research. In the absence of such estimates, managers may have difficulty justifying the importance of treatments, relying instead on anecdotal evidence or untested simulations based on unverified computer algorithms.

Traditionally, the science of fuel treatments has relied heavily on retrospective studies. Speculative, future-looking, landscape modeling simulations are more common recently. While important, both retrospective and futuristic studies may be of limited use in providing insights for managing dynamic fire regimes, especially in the face of unprecedented climate changes. Parsing future fire effects into fuel and climate causes will increasingly challenge researchers and policymakers alike. Future studies will be especially useful 
if they demonstrate improvements in forest resilience while allowing managers to adaptively manipulate ecosystems across diverse landscapes. Fuel treatments can thus provide an opportunity for agencies to collaborate positively with concerned publics and stakeholders, thereby demonstrating stewardship and building trust.

When discussing fuel treatments, distinctions are needed between short-term hazard reduction vs. the long-term when forests are fully sustainable and safe for prescribed fire. During the transition, increasing population densities may actually decrease the areas where prescribed fire can be applied. Costs will be optimized when the long-term ideal is achieved. In the short term, wildfires will treat more of the landscape (and reduce fuels on more area) than planned treatments due in part to the growing backlog of areas requiring fuel reduction. Ostensibly, as more of the fuels across a landscape are treated, then treated areas can be integrated with recent wildfire burns in developing management strategies for future incidents.

For the foreseeable future, the theory and practice of fuel treatments will continue to focus primarily on wildfire hazard reduction, with secondary consideration of ecological integrity of treatments, including resilience to wildfire. In some localities, hazard reduction and ecological restoration will be coupled together. Priorities will be directed toward wildland-urban interface areas with greater values at risk, although more remote areas will continue to burn and garner attention. Fuel treatment theories will likely lag practice for some time to come, but both theory and practice need expansion in order to dent the fire suppression paradigm that feeds a substantial and costly firefighting-industrial complex. Fuel hazard reduction will predominate so long as managers fixate on controlling the spread and growth of wildfires that are perceived as damaging. As perceptions broaden to recognize the need for fire-safe forests, then ecological prerogatives should gain importance, including those related to treatment implementation and subsequent wildfire performance.

The fuel management challenge is to annually treat a sufficient proportion of the area under management to sustain a fire-safe forest in perpetuity. No one has figured out exactly how to do this as it involves a sticky balance between fire use and fire as a destructive force. Pitfalls abound, including breaches between theory and practice, plus human fallibilities when implementing progressive fire and land management trajectories. Theory will never fully match practice, but should provide sufficient foundation to expand needed programs. As a society, we can only hope that the science of treatments eventually facilitates an expansion to the practices prevailing across public and private lands. This will require advances in theory that enlighten management policies, acknowledging fire as both potent adversary and powerful ally.

Acknowledgments The author wishes to thank the Joint Fire Science Program for support of projects that informed the current discussion. He also acknowledges Dr. Tom Zimmerman for informative conversations during this paper's formative stages, Erik Martinson for assistance on numerous projects that informed viewpoints expressed herein, and Dr. Martin Alexander for the invitation to participate with this submission.

Compliance with Ethics Guidelines Dr. Philip N. Omi declares that he has no conflicts of interest to declare.

Human and Animal Rights and Informed Consent This article contains no studies with human or animal subjects performed by the author.

\section{References}

Papers of particular interest, published recently, have been highlighted as:

- Of importance

•. Of major importance

1. Deeming JD. Effects of prescribed fire on wildfire occurrence and severity. In: Walstad JD, Radosevich SR, Sandberg DV, editors. Natural and prescribed fire in Pacific Northwest forests. Corvallis: Oregon State University Press; 1990. p. 95-104.

2. Pyne SJ. Fire in America. A cultural history of wildland and rural fire. Princeton NJ: Princeton University Press; 1982.

3. Schiff AL. Fire and water: scientific heresy in the Forest Service. Cambridge MA: Harvard University Press; 1962.

4. Chandler CC Light burning in southern California fuels. Forest research notes No. 119 Berkeley, CA: USDA Forest Service, California Range and Forest Experiment Station, 1957.

5. Keeley JE, Aplet GH, Christensen NL, Conard SG, Johnson EA, Omi PN, et al. Ecological foundations for fire management in North American forest and shrubland ecosystems. Gen. Tech. Rep. PNWGTR-779. US Department of Agriculture, Forest Service, Pacific NW Research Station.: Portland OR; 2009.

6. Chambers J. The evolution of wildland fire management policy in the US Forest Service. Fire Manag Notes. 1987;48(2):5-8.

7. Stephens SL, Ruth LW. Federal forest-fire policy in the United States. Ecol Appl. 2005;15(2):532-42.

8. Sample VA, Cheng A. Forest Conservation Policy. A reference handbook. Santa Barbara: ABC-CLIO; 2004.

9. Stewart OC Native Americans and the transient wilderness. Edited by Lewis HT, Anderson MK. Norman OK: University of Oklahoma Press. 2002.

10. Wilson KO. Forest fuels management - the problem and the challenge. J For. 1970;68:274-9.

11. Wilson CC, Dell JD. The fuels buildup in American forests: a plan of action and research. J For. 1971;69:471-5.

12. Brackebusch AP. Fuel management: a prerequisite not an alternative to fire management. J For. 1973;71:637-9.

13. Roby GA, Green LR. Mechanical methods of chaparral modification.Agriculture Handbook 487. Washington DC: US Department of Agriculture, Forest Service; 1976.

14. Husari S, Nichols T, Sugihara NG, Stephens SL. Fire and fuel management. Chapter 19. In: Sugihara NG, van Wagtendonk JW, Shaffer KE, Fites-Kaufman J, Thode AE, editors. Fire in California's ecosystems. Berkeley: University of California Press; 2006. p. 444-65.

15. Carle D. Burning questions: America's fight with nature's fire. Westport, CT: Praeger Publishers; 2002.

16. Countryman CM. Can southern California wildland conflagrations be stopped? General Technical Report PSW-7. USDA Forest 
Service, Pacific Southwest Forest and Range Exp. Station: Berkeley, CA; 1974.

17. Salazar L, Gonzalez-Caban A. Spatial relationship of a wildfire, fuelbreaks, and recently burned areas. West J Appl For. 1987;2: $55-8$.

18.• Kreye JK, Brewer NW, Morgan P, Varner JM, Smith AMS, Hoffman CM, et al. Fire behavior in masticated fuels: a review. For Ecol Manag. 2014;314:193-207. Author's note: Mastication has become a widespread practice in the western and southeastern US, often implemented without understanding fire behavior implications of fuel shredding, chipping, and re-arrangement.

19. Kreye JK, Varner JM, Knapp EE. Effects of particle fracturing and moisture content on fire behaviour in masticated fuelbeds burned in a laboratory. Int J Wildland Fire. 2011;20:308-17.

20. Omi PN. Forest fires: a reference handbook. ABC-CLIO: Santa Barbara, CA; 2005.

21. Smith DM, Larson BM, Kelty MJ, Ashton PMS. Theory and practice of silviculture: applied forest ecology. 9th ed. New York: Wiley; 1996.

22. Green LR. Fuelbreaks and other fuel modification for wildland fire control. Washington DC: US Department of Agriculture, Forest Service. Agriculture Handbook 499. 1977.

23. Agee JK, Bahro B, Finney MA, Omi PN, Sapsis DB, Skinner CN, et al. The use of shaded fuelbreaks in landscape fire management. For Ecol Manag. 2000;127:55-66.

24. Finney MA. Design of regular landscape fuel treatment patterns for modifying fire growth and behavior. For Sci. 2001;47:219-28.

25. Binkley D, Fisher RF. Ecology and management of forest soils. 4th ed. West Sussex: Wiley; 2013.

26. Collins BM, Stephens SL. Managing natural wildfires in Sierra Nevada wilderness areas. Front Ecol Environ. 2007;5:523-7.

27.• Collins BM, Miller JD, Thode AE, Kelly M, van Wagtendonk JW, Stephens SL. Interactions among wildland fires in a longestablished Sierra Nevada natural fire area. Ecosystems. 2009;12: 114-28. This study provides insights into natural fire management programs initiated in US national parks since the 1970s. Though questionable in low-elevation developed areas, the backcountry burn patterns over time provide a rationale for allowing lightning ignitions to regulate fuels in fire-regulated forests in remotely-located landscapes.

28. Rogers DH. Measuring the efficiency of fire control in California chaparral. J For. 1942;40:697-703.

29. van Wilgen BW, Govender N, Biggs HC, Ntsala D, Funda XN. Response of savanna fire regimes to changing fire-management regimes in a large African national park. Conserv Biol. 2004;18: 1533-40.

30. Zimmerman T, Lasko R, Kauffman M. Fuel treatment science plan. Boise, ID: National interagency fire center, joint fire science program. 2014. Website. Accessed 5 Oct 2014.

31. National Interagency Fire Center, Incident Management Situation Report, Boise, ID: National Interagency Fire Center, National Incident Coordination Center, Nov. 7, 2014, www.nifc.gov/nicc/ sitreport.pdf, accessed 11 Nov 2014.

32. Barnwell J. Congress: Land swaps, new wilderness, but no wildfire funding bill. In: The Forestry Source 2015;20(1): 20.

33. Gebert K. Effect of suppression strategies on federal wildland fire expenditures. J For. 2011;110:65-73.

34. North M, Collins BM, Stephens S. Using fire to increase the scale, benefits, and future maintenance of fuels treatments. J For. 2012;110:392-401.

35. Reinhardt ED, Keane RE, Calkin DE, Cohen JD. Objectives and considerations for wildland fuel treatment in forested ecosystems of the interior western United States. For Ecol Manag. 2008;256: 1997-2006.
36. Stocks BJ, Alexander ME, Lanoville RA. Overview of the International Crown Fire Modelling Experiment (ICFME). Can J For Res. 2004;34:1543-7.

37. Martinson EJ and Omi PN. Fuel treatments and fire severity: a meta-analysis. Res. Pap. RMRS-RP-103WWW. Fort Collins CO: US Department of Agriculture, Forest Service, Rocky Mountain Research Station, 2013. This study combined results from 19 publications reporting observed fire responses from 62 treated v. untreated contrasts within the meta-analytic framework. While effect size varied, in the aggregate the findings confirm empirically the basic principles proposed in [51], summarized as Table 2 of the current document.

38. Ritchie MW, Skinner CN, Hamilton TA. Probability of tree survival after wildfire in an interior pine forest of northern California: effects of thinning and prescribed fire. For Ecol Manag. 2007;247:200-8.

39. Graham RT, Jain TB, Loseke M. Fuel treatments, fire suppression, and their interactions with wildfire and its effects: the Warm Lake experience during the Cascade Complex of wildfires in central Idaho, 2007. Gen. Tech. Rep. RMRS-GTR-229. US Department of Agriculture, Forest Service, Rocky Mountain Research Station.: Fort Collins CO; 2009.

40. Hudak AT, Rickert I, Morgan P, Strand E, Lewis SA, Robichaud PR, Hoffman C, Holden ZA. Review of fuel treatment effectiveness in forests and rangelands and a case study from the 2007 megafires in central Idaho USA. Gen. Tech. Rep. RMRS-GTR-252 Fort Collins CO: US Department of Agriculture, Forest Service, Rocky Mountain Research Station. 2011.

41. Safford HD, Stevens JT, Merriam K, Meyer MD, Latimer AM. Fuel treatment effectiveness in California yellow pine and mixed conifer forests. For Ecol Manag. 2012;274:17-28.

42. Wimberly MC, Cochrane MA, Baer AD, Pabst K. Assessing fuel treatment effectiveness using satellite imagery and spatial statistics. Ecol Appl. 2009;19:1377-84.

43.• Stevens JT, Safford HD, Latimer AM. Wildfire-contingent effects of fuel treatments can promote ecological resilience in seasonally dry conifer forests. Can J For Res. 2014;44:843-54. This paper confirms that fuel treatments can contribute to the restoration and sustainability of certain forest types by increasing their resilience to recurrent wildfire events.

44. Shephard RW, Jewell WS. Operations research in forest fire problems. Berkeley CA: Operations Research Center, Institute of Engineering Research, University of California, Berkeley; 1961.

45. Byram GM. Combustion of forest fuels. Chapter 3 In: Davis KP, ed. Forest fire: control and use. New York: McGraw-Hill: 1959; p 6189.

46. Graham RT, McCaffrey S, Jain TB. Science basis for changing forest structure to modify wildfire behavior and severity. Gen. Tech. Rep. RMRS-GTR-120. US Department of Agriculture, Forest Service, Rocky Mountain Research Station.: Fort Collins CO; 2004.

47. Peterson DL, Johnson MC, Agee JK, Jain TB, McKenzie D, Reinhardt ED. Forest structure and fire hazard in dry forest of Western United States. Gen. Tech. Rep. PNW-GTR-628. US Department of Agriculture, Forest Service, Pacific Northwest Research Station.: Portland OR; 2005.

48. Hunter ME, Shepperd WD, Lentile JE, Lundquist JE, Andreu MG, Butler JL, et al. A comprehensive guide to fuels treatment practices for ponderosa pine in the Black Hills, Colorado Front Range, and Southwest. Gen. Tech. Rep. RMRS-GTR-198. US Department of Agriculture, Forest Service, Rocky Mountain Research Station.: Fort Collins CO; 2007.

49. Evans AM, Everett RG, Stephens SL, Youtz JA. Comprehensive fuels treatment practices guide for mixed conifer forests: California, central and southern Rockies, and the Southwest. Forest Guild: Santa Fe NM; 2011. 
50. Jain TB, Battaglia MA, Han HS, Graham RT, Keyes CR, Fried JS, Sandquist JE. A comprehensive guide to fuel management practices for dry mixed conifer forests in northwestern United States. Gen. Tech. Rep. RMRS-GTR-292. Fort Collins, CO: US Department of Agriculture, Forest Service, Rocky Mountain Research Station. 2012. Author's note: This report provides a summary of treatments and effects under one cover. Though focused on the northwestern US, findings are applicable to dry mixed conifer forests found elsewhere.

51. Agee JK, Skinner CN. Basic principles of forest fuel reduction treatments. For Ecol Manag. 2005;211:83-96.

52. Raymond C, Peterson DL. How did prefire treatments affect the Biscuit Fire? Fire Management Today. 2005;65(2):18-22.

53. Anderson HE. Aids to determining fuel models for estimating fire behavior. Gen. Tech. Rep. INT-122. US Department of Agriculture, Forest Service, Intermountain Forest and Range Experiment Station.: Ogden UT; 1982.

54. Scott JH, Burgan RE. Standard fire behavior fuel models: a comprehensive set for use with Rothermel's surface fire spread model. Gen. Tech. Rep. RMRS-GTR-153. US Department of Agriculture, Forest Service, Rocky Mountain Research Station.: Fort Collins $\mathrm{CO} ; 2005$.

55. Burgan RE, Rothermel RC. BEHAVE: Fire behavior prediction and fuel modeling system-FUEL subsystem. Gen. Tech. Rep. INT167. US Department of Agriculture, Forest Service, Intermountain Forest and Range Experiment Station.: Ogden UT; 1984.

56. Rothermel RC. A mathematical model for fire spread predictions in wildland fuels. Res. Pap. INT-115. US Department of Agriculture, Forest Service, Intermountain Forest and Range Experiment Station.: Ogden UT; 1972.

57. Van Wagner CE. The line intersect method in forest fuel sampling. For Sci. 1968;14:20-6.

58. Brown JK. Handbook for inventorying surface fuels and biomass in the Interior West. Gen. Tech. Rep. INT-129. USDA Forest Service, Intermountain Forest and Range Experiment Station.: Ogden UT; 1982.

59. Rollins MG. LANDFIRE: a nationally consistent vegetation, wildland fire, and fuel assessment. Int J Wildland Fire. 2009;18:235-49.

60. Krasnow K, Schoennagel T, Veblen TT. Forest fuel mapping and evaluation of LANDFIRE fuel maps in Boulder County, Colorado, USA. For Ecol Manag. 2009;257:203-12.

61. McIver JD, Fettig CJ. Ecological consequences of alternative fuel reduction treatments in seasonally dry forests: the national fire and fire surrogate study. For Sci. 2010;56:2-3.

62.• Stephens SL, McIver JD, Boerner REJ, Fettig CJ, Fontaine JB, Hartsough BR, et al. The effects of forest fuel reduction treatments in the United States. Bioscience. 2012;62:549-60. This paper essentially documents the ephemeral impacts of fuel treatments in dry coniferous forests, thereby mitigating potential ecological or environmental concerns about prescribed fire and mechanical alternatives.

63. Leopold A. Round river. New York: Oxford University Press; 1993.

64. Amiro BD, Stocks BJ, Alexander ME, Flannigan MD, Wottom BM. Fire, climate change, carbon and fuel management in the Canadian boreal forest. Int J Wildland Fire. 2001;10:405-13.

65. Hunter ME, Omi PN, Martinson EJ, Chong GW. Establishment of non-native plant species after wildfires: effects of fuel treatments, abiotic and biotic factors, and post-fire grass seeding treatments. Int J Wildland Fire. 2006;15:271-81.

66. Freeman JP, Stohlgren TJ, Hunter ME, Omi PN, Martinson EJ, Chong GW, et al. [2007]. Rapid assessment of postfire plant invasions in coniferous forests of the western United States. Ecol Appl. 2007; 17:1656-65.

67. Knapp EE, Varner JM, Busse MD, Skinner CN, Shestak CJ. Behaviour and effects of prescribed fire in masticated fuelbeds. Int J Wildland Fire. 2011;20:932-45.
68. Rapp V. Tested by fire: what happens when wildfires meet fuel treatments? Boise, ID: Joint Fire Science Brief Issue 1. 2007.

69. Alexander ME. Are we abusing our use of models and modeling in wildland fire and fuel management? Fire Management Today. 2009;69(4):23-6.

70. Wu Z, He HS, Liu Z, Liang Y. Comparing fuel reduction treatments for reducing wildfire size and intensity in a boreal forest landscape of northeastern China. Sci Total Environ. 2013;454-455:30-9.

71. Cochrane MA, Moran CJ, Wimberley MC, Baer AD, Finney MA, Beckendorf KL, et al. Estimation of wildfire size and risk changes due to fuels treatment. Int J Wildland Fire. 2012;21:357-67.

72. Johnson MC, Kennedy MC, Peterson DL. Simulating fuel treatment effects in dry forests of the western United States: testing the principles of a fire-safe forest. For Ecol Manag. 2011;211:8396.

73. Syphard AD, Scheller RM, Ward BC, Spencer WD, Strittholt JR. Simulating landscape-scale effects of fuels treatments in the Sierra Nevada, California, USA. Int J Wildland Fire. 2011;20:364-83.

74. Ager AA, Vaillant NM, Finney MA. A comparison of landscape fuel treatment strategies to mitigate wildland fire risk in the urban interface and preserve old forest structure. For Ecol Manag. 2010;259:1350-570.

75. Schmidt DA, Skinner CN, Taylor AH. The influence of fuels treatment and landscape arrangement on simulated fire behavior, Southern Cascade range, California. For Ecol Manag. 2008;215: 3170-84.

76. Finney MA, Seli RC, McHugh CW, Ager AA, Bahro B, Agee JK. Simulation of long-term landscape-level fuel treatment effects on large wildfires. Int J Wildland Fire. 2007;16:712-27.

77. Ager AA, McMahan AJ, Barrett JJ, McHugh CW. A simulation study of thinning and fuel treatments on a wildland-urban interface in eastern Oregon, USA. Landsc Urban Plan. 2007;80:292-300.

78. Ager AA, Finney MA, Kerns BK, Maffei H. Modeling wildfire risk to northern spotted owl (Strix occidentalis caurina) habitat in Central Oregon, USA. For Ecol Manag. 2007;246:45-56.

79. Stratton RD. Effectiveness of landscape fuel treatments on fire growth and behavior. J For. 2004;102(7):32-40.

80. Sturtevant AD, Scheller RM, Miranda BR, Shinneman D, Syphard D. Simulating dynamic and mixed-severity fire regimes: a processbased fire extension for LANDIS-II. Ecol Model. 2009;220:3380 93.

81. Scott JH, Reinhardt ED. Assessing crown fire potential by linking models of surface and crown fire behavior. Research Paper RMRSRP-29. USDA Forest Service Rocky Mountain Research Station.: Fort Collins, CO; 2001.

82. He HS, Shang ZB, Thomas RC, Gustafson EJ, Shifley SR. Simulating forest fuel and fire risk dynamics across landscapesLANDIS, fuel model design. Ecol Model. 2004;180:135-51.

83. Finney MA. FARSITE: Fire Area Simulator-model development and evaluation. Research Paper RMRS-RP-4 revised. Ogden: USDA Forest Service, Rocky Mountain Research Station; 2004.

84. Reinhardt E, Crookston NL. The fire and fuels extension to the Forest Vegetation Simulator. General Technical Report GTRRMRS 116. US Department of Agriculture, Forest Service, Rocky Mountain Research Station.: Fort Collins CO; 2003.

85. Ager AA, Vaillant NM, Finney MA. Integrating fire behavior models and geospatial analysis for wildland fire risk assessment and fuel management planning. Journal of Combustion 2011;Article ID 572452.

86. Finney MA. Fire growth using minimum travel time methods. Can J For Res. 2002;32:1420-4.

87. Soverel NO, Perrakis DDB, Coops NC. Estimating burn severity from Landsat dNBR and RdNBR indices across western Canada. Remote Sens Environ. 2010;114:1896-909.

88. Finney, MA. An overview of FlamMap fire modeling capabilities. p. 213-220. In: Andrews, P.L. and Butler, B.W. comps. 2006. Fuels 
management- how to measure success: conference proceedings. 28-30 March 2006; Portland OR. Proceedings RMRS-P-41. Fort Collins CO: US Department of Agriculture, Forest Service, Rocky Mountain Research Station. 2006.

89. Linn RR, Cunningham P. Numerical simulations of grassfires using coupled atmosphere-fire model: basic fire behavior and dependence of wind speed. J Geophys Res. 2005;110, D131007.

90. Mell W, Jenkins MA, Gould J, Cheney P. A physics-based approach to modelling grassland fires. Int J Wildland Fire. 2007;16: $1-22$.

91. Alexander ME, Cruz MG. Are the applications of wildland fire behaviour models getting ahead of their evaluation again? Environ Model Softw. 2013;41:65-71.

92. Calkin DE, Ager AA, Gilbertson-Day J. eds. Wildfire risk and hazard: procedures for the first approximation. Gen. Tech. Rep. RMRS-GTR-235. US Department of Agriculture, Forest Service, Rocky Mountain Research Station.: Fort Collins CO; 2010.

93. McCaffrey SM, Olsen CS. Research perspectives on the public and fire management: a synthesis of current social science on eight essential questions. Gen. Tech. Rep. NRS-104. US Department of Agriculture, Forest Service, Northern Research Station.: Newtown Square PA; 2012.

94. Omi PN, Miller M, Martinson EJ, Kaufmann MR. Fuel treatmentline of work. A science plan for meeting research needs. Joint Fire Science Program. Boise, ID: http://www.firescience.gov/ documents/fuels/fuels_treatment_science_plan_110110.pdf. 2010. Accessed 13 Dec $201 \overline{4}$.

95. GAO. Wildland fire management: better information and a systematic process could improve agencies' approach to allocation fuel reduction funds and selecting projects. Washington DC: Government Accounting Office circular GAO-07-116. 2007.

96. GAO. Wildland fire management: federal agencies have taken important steps forward, but additional strategic action is needed to capitalize on those steps. Washington DC: Government accounting office circular GAO-09-887. 2009.

97. Simard AJ. Wildland fire management: economics of policy alternatives. Ottawa, Canada: department of the environment, Canadian forestry service, forestry technical report 15. 1976. 